С. М. Муравська

\title{
КОМУНІКАТИВНО ЗОРІЕНТОВАНИЙ ПІДХІД У НАВЧАННІ АНГЛОМОВНОГО СПІЛКУВАННЯ МАЙБУТНІХ АВІАФАХІВЦІВ
}

\begin{abstract}
Муравська С. М. Комунікативно зорієнтований підхід у навчанні англомовного спілкування майбутніх авіафахівців.

У статті обгрунтовано доцільність використання комунікативно зорієнтованого підходу до навчання майбутніх авіафахівців англомовного спілкування. Запропоновано потрактування категорії «комунікація» як ключового поняття комунікативного підходу. Представлено принципи комунікативного навчання, сформульовані Є. Пасовим: принципи мовленнєво-розумової активності, індивідуалізації, функціональності, ситуативності, новизни. Визначено чинники ефективного застосування комунікативного підходу та тенденції, релевантні для викладання іноземної мови: комунікативна спрямованість усіх видів навчання; основною ланкою у процесі навчання $є$ не викладач, а студент; зацікавлення студентів процесом навчання відповідно до їхніх інтересів, здібностей і потреб; навчально-методичні матеріали подаються за ситуативнотематичним чи функціональним принципом; основними видами роботи студентів $\epsilon$ парна (діалог) і групова (полілог) робота; комунікативний підхід до вивчення мови спричинив нетрадиційне ставлення до помилки. 3-поміж недоліків комунікативного підходу виокремлено несистематичне подання граматичного матеріалу.

Ключові слова: комунікативно зорієнтований підхід, англомовне спілкування, комунікація, чинники ефективного застосування, тенденції, викладання іноземної мови.
\end{abstract}

Муравская С. Н. Коммуникативно направленный подход в обучении общению на английском языке будущих авиаспециалистов.

В статье обосновывается целесообразность использования коммуникативно направленного подхода в обучении будущих авиаспециалистов общению на английском языке. Предлагается определение категории «коммуникация» как ключевого понятия коммуникативного подхода. Анализируются сформулированные Е. Пассовым принципы коммуникативного обучения: речевой и умственной активности, (с) С. М. Муравська, 2016. 
индивидуализации, функциональности, ситуативности, новизны. Определяются факторы эффективного применения коммуникативного подхода и тенденции, характерные для преподавания иностранного языка: коммуникативная направленность всех видов обучения; главным звеном в процессе обучения является не преподаватель, а студент; заинтересованность студентов процессом обучения согласно с их интересами, способностями и потребностями; учебно-методические материалы предоставляются за ситуативно-тематическим или функциональным принципом; основными видами работы студентов являются работа в парах (диалог) и в группах (полилог); коммуникативный подход в изучении языка способствовал появлению нетрадиционного отношения $\mathrm{k}$ ошибке. Среди недостатков коммуникативного подхода следует отметить несистематическую подачу грамматического материала.

Ключевые слова: коммуникативный подход, общение на английском языке, коммуникация, условия эффективного использования, тенденции, преподавание иностранного языка.

Muravska S. M. Communicative approach in the process of teaching future aviation specialists to speak English.

The reasonability of using communicative approach in the process of teaching future aviation specialists to speak English has been proved in the given article. The definition of the term "communication" as a basic notion of communicative approach has been offered. Communication can be defined as exchange of thoughts and information. Formulated by E. Passov principles of communicative learning have been presented: the principle of speaking and mental activity, the principle of individualization, the principle of functionality, the situational principle and the principle of novelty. The conditions of effective application of communicative approach and tendencies relevant for teaching a foreign language have been defined. The tendencies are the following: communicative orientation of all kinds of learning; the main link in the teaching process is not a teacher but a student; making students interested in the learning process according to their interests, abilities and needs; teaching materials are presented according to situational and subject or functional principle; the main types of interaction are pair and group work; communicative approach in the process of learning a language has contributed into appearing of non-traditional attitude towards errors. One of the drawbacks of communicative approach is unsystematic presentation of grammar material.

In the process of research it has been found out that success of implementation of communicative approach depends on a number of factors: the level of teacher's professional training; knowledge of cadets' individual peculiarities and abilities; usage of authentic teaching materials; formation of cadets' communicative competency with the help of four kinds of activities, such as reading, writing, speaking and listening. The author of the article points out the term «approach» means the strategy of teaching. The fundamental principle of communicative approach is focusing on communicative competency as a basic one, spontaneity and natural character of communication process, considering students' individual peculiarities, abilities, interests and future job possibilities.

Having conducted the research we have come to the conclusion that communicative approach can be successfully implemented in the process of teaching future aviation specialists to speak English. Pair work is the most common type of activity as communication in real life takes place between a pilot and an air traffic controller. Group 
work is also very popular as it helps students to overcome language barrier and fear of speaking. The students are asked to agree or disagree with the given statements, to find solutions to different problem situations.

Key words: communicative approach, speaking English, communication, conditions of effective application, tendencies, teaching a foreign language.

В умовах світової глобалізації й інтеграції України у європейський освітній простір кардинально змінюється мета навчання іноземної мови у вищих навчальних закладах. Вона визначається потребами сучасного суспільства, розвитком інформаційних технологій, світовими стандартами підготовки якісних фахівців, можливістю отримання освіти чи працевлаштування за кордоном.

Досвід свідчить про те, що відбувається перехід від репродуктивного способу навчання до навчання, яке потребує активної діяльності особистості. На зміну традиційним методам навчання іноземної мови приходять інноваційні, інтерактивні методи навчання, які роблять акцент на спілкуванні.

Сфера авіації становить особливий інтерес у межах нашого дослідження. Спілкування пілотів та диспетчерів відбувається за допомогою стандартної фразеології, яка містить набір фраз, призначених для тих чи тих професійних ситуацій. Знання фразеології $\epsilon$ достатнім у 95\% спілкування. Проте трапляються нестандартні ситуації, у яких вільне володіння англійською мовою диспетчером і пілотом може врятувати життя екіпажу та пасажирам. Статистика засвідчує: якщо в минулому столітті основною причиною авіакатастроф виступав технічний фактор, то в наш час перше місце займає людський фактор. Тому якісна підготовка диспетчерів і пілотів вимагає знань не лише авіаційної англійської мови, але й загальновживаної англійської мови. Вільне володіння іноземною мовою є неможливим без застосування комунікативно зорієнтованого підходу.

Науково-теоретичні дослідження 3 загальної практики викладання іноземних мов представлені у працях педагогів і психологів, як-от: І. Бім, Д. Брунер, Н. Бориско, Д. Грін, Н. Гез, I. Зимня, Г. Китайгородська, Л. Кунч, О. Леонтьєв, М. Макош, ๑ С. М. Муравська, 2016. 
Р. Мільруд, Є. Пасов, Д. Уілкінс, Д. Хаймз, С. Шатілов, Л. Щерба.

Мета статті полягає в тому, щоб обгрунтувати доцільність використання комунікативно зоріснтовного підходу у процесі навчання майбутніх авіафахівців англомовного спілкування.

Термін «підхід», як відомо, потрактовують як стратегію навчання. Основою комунікативно зорієнтованого підходу $\epsilon$ переорієнтація на комунікативну компетенцію як провідну, на спонтанність і природність комунікації й урахування індивідуальних особливостей студентів.

Комунікація як ключове поняття комунікативного підходу $є$ синонімом до «спілкування», оскільки 3 латинської communicatio означає «повідомлення», «спілкування», «передача», «зв’язок» універсальне поняття, що використовується всіма науками [6, с. 154]. Філософський словник витлумачує «комунікацію» як «спілкування, обмін думками, інформацією» [7].

Цікавою $є$ думка Д. Філіпса, який зазначав, що комунікативний підхід $є$ «спробою уникнути формальних (або традиційних) підходів, що грунтуються на граматиці і перекладах, і перейти до підходів, за допомогою яких студент використовуватиме мову як засіб спілкування» [9, с. 94]. Відповідно до тверджень Р. Скотта, усна комунікативність (спілкування) - це тип діяльності, що передбачає спілкування двох чи більше осіб і у якому обидва учасники є слухачами і співрозмовниками одночасно: вони повинні реагувати на те, що чують через репліки $[8$, с. 70]. На думку сучасного науковця С. Король, суть комунікативного підходу полягає в тому, щоб передати студентам не знання про мову як систему, а озброїти їх мовленнєвими уміннями й навичками для практичного застосування в будь-якій іншомовній мовленнєвій ситуації. Відтак - комунікативно зорієнтований метод навчання іноземних мов покликаний наблизити тих, хто вивчає іноземну мову, до реальних умов спілкування [2, с. 133].

Сформульовані С. Пасовим принципи комунікативного навчання іноземної мови дають змогу отримати найбільш повне 
уявлення про комунікативний підхід.

Принцип мовленнєво-розумової активності передбачає передусім таку організацію навчання, за якої студенти постійно задіяні у процесі спілкування. Для того, щоб забезпечити єдність мислення й мовлення у процесі навчання спілкування, необхідно насамперед попіклуватися про активізацію мовленнєво-розумової діяльності студентів. Згідно 3 цим принципом змістовою основою комунікативного навчання виступає проблемність. Для організації процесу навчання спілкування необхідно здійснити вибір тих проблем і проблемних ситуацій, які здатні активізувати розумову діяльність студентів та викликати в них потребу в їх обговоренні [3, с. 120-121]. При навчанні майбутніх авіафахівців слід обирати теми для спілкування, пов’язані з їхньою професійною діяльністю.

Принции індивідуалізащіï. Є. Пасов вважає цей принцип серцевиною комунікативного навчання, одним із основних засобів створення мотивації. Для підтвердження своєї думки дослідник цитує Г. Рогову, а саме: «навчання іноземної мови, мабуть, більшою мірою, ніж навчання будь-якого іншого предмета, потребує індивідуального підходу» [5, с. 46]. У процесі спілкування з майбутніми авіафахівцями ми завжди повинні враховувати індивідуальні особливості студентів, а якщо навчаємо іноземців, повинні брати до уваги і їхні культурні та релігійні особливості, специфіку виховання, світогляду тощо.

Принции функиіональності є багатоаспектним, однак передовсім акцентує увагу на функціональному відборі й організації мовленнєвих засобів.

Приничи ситуативності передбачає визнання ситуації як одиниці організації процесу навчання іншомовного спілкування. Ситуація в комунікативному навчанні забезпечує презентацію мовленнєвого матеріалу, формування мовленнєвих навичок, здатних до переносу; розвиток таких характеристик, як цілеспрямованість, динамічність, продуктивність і т. ін.

Принции новизни охоплює весь навчальний процес, а його ๑ С. М. Муравська, 2016. 
реалізація надзвичайно важлива для успішності комунікативного навчання. Новизна стосується змісту матеріалів (текстів, вправ), умов навчання (організації навчання), прийомів навчання, форм організації навчального процесу тощо. Він забезпечує підтримку інтересу до навчання, формування мовленнєвих навичок, розвиток продуктивних $\mathrm{i}$ динамічних мовленнєвих умінь, розвиток комунікативної функції мовлення [3, с. 123].

Усі представлені вище принципи є актуальними у процесі навчання майбутніх авіафахівців. Як зауважує В. Причина, ефективність забезпечення такого підходу залежить від певних чинників, а саме:

1. Рівня професійної майстерності педагога, зумовленої його інтелектуальними, творчими й організаторськими здібностями.

2. Знання індивідуальних особливостей і природних здібностей курсантів задля створення сприятливих умов щодо реалізації їхніх пізнавальних можливостей, потреб, інтересів.

3. Використання комунікативно зорієнтованих навчальнометодичних видань: Oxford University Press, Longman, Express Publishing. Завдання та вправи у цих підручниках $є$ реалістичними й мотивувальними, стосуються широкого кола освітніх, соціальних, авіаційних тем, містять достатню кількість автентичного матеріалу.

4. Формування у студентів уміння спілкуватися англійською мовою за допомогою чотирьох видів мовленнєвої діяльності: говоріння, слухання, читання, письма [4, с. 195].

Як наголошує В. Вдовін, комунікативний підхід є зорієнтованим на вивчення мови через спілкування. Використання мови в реальній комунікативній ситуації спричинило в межах комунікативного підходу деякі тенденції, релевантні для викладання іноземної мови:

1) комунікативна спрямованість усіх видів навчання;

2) основною ланкою у процесі навчання $\epsilon$ не викладач, а студент («learner-centred approach»);

3) зацікавлення студентів процесом навчання відповідно до їхніх інтересів, здібностей і потреб («the whole person approach»); 
4) навчально-методичні матеріали подаються за ситуативнотематичним чи функціональним принципом;

5) основними видами роботи студентів $є$ парна (діалог) i групова (полілог робота;

6) комунікативний підхід до вивчення мови сприяв появі нетрадиційного ставлення до помилки. Виникають питання: Що вважати помилкою? Яка іï природа? [1, с 16]. Помилки є цілком закономірним явищем, на помилках ми вчимося.

Якщо вести мову про навчання майбутніх авіафахівців англомовного спілкування, то тут необхідно зазначити: парна робота $\epsilon$ основним видом, оскільки пілот завжди спілкується 3 диспетчером, допоміжний персонал завжди спілкується з пасажирами, які очікують на свій рейс у будівлі аеровокзалу. Групова робота теж використовується на заняттях. У групах студенти, наприклад, повинні погодитися чи не погодитися 3 такими твердженнями: History of aviation is written with blood; A modern airport is a centre of diversified services; Do you believe in unmanned aviation? Крім того, у групах варто знайти вирішення проблемних ситуацій: What measures should be taken in case of engine failure? What is necessary to be a perfect pilot? What things should be improved in modern planes to prevent the number of air crashes? If you were to create a museum of history of aviation, what would it look like?

Цілком погоджуємося із зазначеною вище тенденцією, що основну роль у процесі навчання за комунікативним підходом відіграє студент. Комунікативний підхід передбачає іншу роль викладача в навчальному процесі. Він полегшує навчання студента, залучаючи його до ситуації на зразок «студент-студент» у вищому ступені, ніж до ситуації «викладач-студент». Для полегшення роботи студентів викладач має виконувати багато ролей. Наприклад, він є менеджером різних видів діяльності в навчальній аудиторії. Ця роль передбачає побудову ситуацій, зручних для спілкування. Під час роботи викладач працює як радник, відповідаючи на запитання студентів і скеровуючи їхню роботу. 3 іншого боку, викладач може бути співрозмовником та 
учасником процесу навчання разом зі студентами. Загалом роль викладача за цих умов менш домінувальна, що йому дає змогу не бути в центрі уваги безпосередньо під час роботи, у той час як студенти можуть відчути себе повноцінними учасниками спілкування.

Комунікативний підхід змінює роль студентів у навчальному процесі: вони є учасниками спілкування, несуть відповідальність за результати свого навчання, намагаються порозумітися, знайти спільне рішення. Студенти розуміють, що завдяки вільному володінню іноземною мовою перед ними відкриваються широкі перспективи й унікальні можливості.

Комунікативна методика викладання іноземних мов демонструє, що основну роль відіграє спілкування, діалогічне мовлення, спонтанне мовлення, при цьому акцентується на реальному спілкуванні. Підручники комунікативного спрямування містять автентичні навчальні матеріали. Завдання до текстів чи теми будуються так, що спонукають студентів до висловлювання власної позиції, звернення до особистого життєвого досвіду. Однак варто пам'ятати про те, що комунікативному підходу притаманні й певні недоліки, 3-поміж яких дослідники вирізняють несистемне подання граматичного матеріалу, оскільки звертається увага лише на граматичні явища, необхідні для спілкування.

Підсумовуючи, зазначимо: сьогодення вимагає від пілотів, диспетчерів, допоміжного персоналу аеропорту вільного володіння англійською мовою. Знання фразеології радіообміну здебільшого $є$ достатнім, проте завжди існує вірогідність нештатних ситуацій, коли швидке реагування й користування мовою як інструментом може врятувати життя сотням або тисячам людей. Саме комунікативний підхід $€$ основним засобом навчання майбутніх авіафахівців англомовного спілкування.

\section{Література}

1. Вдовін В. В. Комунікативний підхід як оптимальний засіб вивчення іноземної мови у ВН3 / В.В. Вдовін // Вісник Національного університету «Львівська політехніка». - 2007. - № 586. - С. 15-20. 
2. Король С. В. Комунікативний підхід у навчанні іноземних мов / С. В. Король // Педагогічний дискурс. - 2012. - Вип. 11. - С. 133-136.

3. Пассов Е. И. Основы коммуникативной методики обучения иноязычному общению / Е. И. Пассов. - М. : Русский язык, 1989. - 276 с.

4. Причина В. В. Комунікативно зорієнтований підхід до навчання учнів англомовного спілкування / В. В. Причина // Таврійський вісник освіти. -2012 . - № 4 (40). - C. 195-201.

5. Рогова Г. В. Повышение эффективности обучения иностранным языкам за счет улучшения психологического климата на уроке / Г. В. Рогова // Иностранные языки в школе. - 1977. - № 5. - С. 46.

6. Соковкин В. Н. О природе человеческого общения / В. Н. Соковкин. - Фрунзе : Мехтеп, 1973. - $154 \mathrm{c}$.

7. Философский энциклопедический словарь / [под ред. Л. Ф. Ильечева]. - М. : Сов. энциклопедия, 1983. $-893 \mathrm{c}$.

8. Johnson K. Communication in the classroom / K. Johnson, K. Morrow. - Longman Group, 1992. - $140 \mathrm{p}$.

9. Philips D. Language in Schools / D. Philips // From Complacency to Conviction. CILT. - 1988. - P.12.

Стаття надійшла до редакиії 06.09.2016 p. 